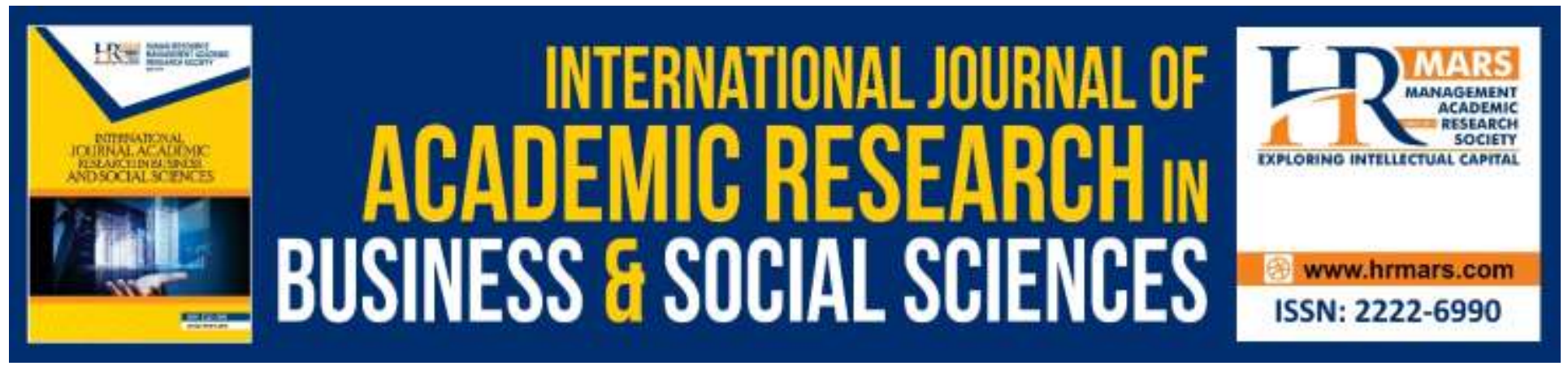

\title{
The Influence of Contextual Elements on Technopreneurial Intention
}

\author{
Mohd Rusydi Abdul Rahim, Wei-Loon Koe, Mohd Halim Mahpoth
}

To Link this Article: http://dx.doi.org/10.6007/IJARBSS/v10-i6/7380

DOI:10.6007/IJARBSS/v10-i6/7380

Received: 20 March 2020, Revised: 28 May 2020, Accepted: 14 June 2020

Published Online: 27 June 2020

In-Text Citation: (Rahim et al., 2020)

To Cite this Article: Rahim, M. R. A., Koe, W.-L., \& Mahpoth, M. H. (2020). The Influence of Contextual Elements on Technopreneurial Intention. International Journal of Academic Research in Business and Social Sciences, 10(6), 862-871.

Copyright: (c) 2020 The Author(s)

Published by Human Resource Management Academic Research Society (www.hrmars.com)

This article is published under the Creative Commons Attribution (CC BY 4.0) license. Anyone may reproduce, distribute, translate and create derivative works of this article (for both commercial and non-commercial purposes), subject to full attribution to the original publication and authors. The full terms of this license may be seen at: $\underline{\text { http://creativecommons.org/licences/by/4.0/legalcode }}$

Vol. 10, No. 6, 2020, Pg. 862 - 871

http://hrmars.com/index.php/pages/detail/IJARBSS

JOURNAL HOMEPAGE

Full Terms \& Conditions of access and use can be found at http://hrmars.com/index.php/pages/detail/publication-ethics 


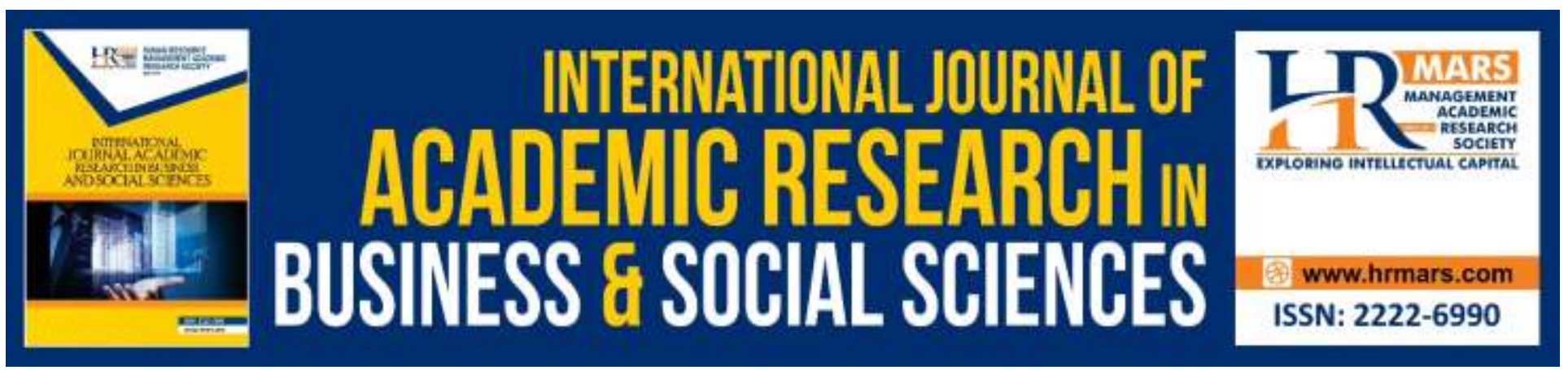

\title{
The Influence of Contextual Elements on Technopreneurial Intention
}

\author{
Mohd Rusydi Abdul Rahim, Wei-Loon Koe, Mohd Halim Mahpoth \\ Faculty of Business \& Management, Universiti Teknologi MARA, Malaysia \\ Email: mohdrusydi30@gmail.com
}

\begin{abstract}
Technoprenuership is a combination of technology and entrepreneurship. High-technology context has been apply in this type of entrepreneur. The purpose of this study is to identify technopreneurial intention among Bumiputera university students in Malaysia. This study specifically examined the direct influence of contextual elements on technopreneurial intention through individual entrepreneurial orientation (IEO). Quantitative research method has been applied and 150 respondents has been take part in this study. Simple random sampling method has been employed to obtain data from the respondents and the data were analysed using Statistical Package for Social Science (SPSS) version 25. The results indicated that contextual element positively and significantly related to technopreneurial intention. Moreover, the results also showed a significant partially mediating role of individual entrepreneurial orientation and technopreneurial intention. Thus, this study contributed a few vital factors in technology based entrepreneurship intention or known as technopreneurial intention as well promoting young entrepreneurship towards university students in Malaysia.
\end{abstract}

Keywords: Entrepreneurship, Technopreneur, Intention, Individual Entrepreneurial Orientation (IEO), Environmental Factor

\section{Introduction}

Entrepreneur play an important role in economic development specifically in developing countries by creating jobs, new technologies, increasing productivity as well increase of economic growth of the country. Industrial revolution 4.0 or known as IR 4.0 is the current trending era in the world where information communication technology (ICT) is essential in the every business operations. In a simple terms, IR 4.0 is about comprehensive digitalisation where focus on digital technology in business operation and services. An entrepreneur whose business involves in advanced technology or intensive technology context are known as technopreneur. This type entrepreneur plays a major role in the new era of industrial revolution 4.0 (IR 4.0). According to World Bank Group report, Malaysia is still lags behind in adopting digital technology and business are connected to internet is only $62 \%$. In addition, only $18 \%$ have online web presence and only $46 \%$ has fixed broadband where is often bad and low quality. In simple words, the number of Malaysian businesses 
which use and adopt digital technology in operation and services is still low. When this happen, a lot disadvantages for Malaysia government to be develop country in the world. This was supported from the report of Earnest \& Young, (2019) where the majority of SME in Malaysia are in early stages of digital maturity which is $62.7 \%$ versus Southeast Asia which is $54.9 \%$. In addition, only $6.8 \%$ of Malaysia SME's at level five of digital maturity compare to Southeast Asia which is $8.7 \%$, where at this level, an organisations have a single digital platform to scale technological innovations and consider themselves digital native enterprises compare to Southeast Asia which is $8.7 \%$. According to Global Entrepreneur Monitor (GEM) report in 2017, it recorded that Malaysian still low intentions to start up new business where only $3.82 \%$ compare to $4.70 \%$ in 2016 and also low and declining early-stage of entrepreneurship rate. In conclusion, adopting digitalisation in business operations in Malaysia still big challenging.

As the new era IR 4.0 been introduced worldwide, Malaysia also has announce Malaysia Education Blueprint 2015-2025 (Higher Education) or known as MEB (HE). This blueprint will make Malaysia education ecosystem on track with IR 4.0 and one of the aim of this blueprint is forming greater chances for students to grow entrepreneurial skill and create their own business. Moreover, this blueprint encourages students to be an entrepreneur specifically in technology that related with the IR 4.0 such as artificial intelligence (AI), augmented reality (AR), IoT, robotics and others. However, Bernama (2017) reported that, only three percent become entrepreneur from the total $60 \%$ student joint entrepreneurship activities and program where lower than the government target. Malaysia still need more students to join in entrepreneur profession.

Contextual element can be related with environment factor. Where the values, personalities, confidence and environment (contextual element) is the background factor that can influenced the entrepreneurial intention. This background factors had greater influence and believed as contributor to entrepreneurial intention and decision rather than personality part. In addition, contextual element was recognised as an environmental factor related to the concept entrepreneurship supports and barriers. Moreover, many researcher has using contextual element as factor influence on entrepreneurial intention. Based on above, there are many previous study examining this variables such as Kristiansen and Indarti, 2003; Setiobudi and Herdinata, 2018; Ramayah and Harun, 2005. However, limited study related with technopreneurial intention. The study about technopreneurial topic such as intention to be technopreneur as well mediating factor which is individual entrepreneurial orientation (IEO) also limited and scared. In addition, in the Malaysia context, a study that focus on technopreneur also limited. This paper intend to fill the gaps by focusing and exploring on aspects pertaining to technopreneurship topic and giving a clear picture about technology not just helping people doing work in daily life but also can make people to be richest person. In particular, the aim of this research is to study the direct relationship between contextual elements, individual entrepreneurial orientation (IEO) and technopreneurial intention.

\section{Literature Review}

Entrepreneurial topic is widely has been study in the world of research as entrepreneur play vital role in the economic growth of a country. This topic is very commonly including the factor influence intention to be entrepreneur. According to Krueger and Brazeal (1994), environment factor is one of the factor influence entrepreneurial intention where contextual element is a part of environment factor. Many studies have found the direct relationship contextual element toward 
INTERNATIONAL JOURNAL OF ACADEMIC RESEARCH IN BUSINESS AND SOCIAL SCIENCES

Vol. 10, No. 6, June, 2020, E-ISSN: 2222-6990 @ 2020 HRMARS

entrepreneurial intention. However, in the context of technopreneurial intention is not been fully explore and limited studies.

Individual entrepreneurial orientation (IEO) is originated from entrepreneurial orientation (EO) concept from Miller (1983) and later has been refined as multidimensional construct by Lumpkin and Dess (1996). Many studies has using IEO as related construct on entrepreneurship for example study on multiple dimension IEO on Norwegian student by Robinson and Stubberud (2014). After the end of an entrepreneurship course, the researcher found majority students showed higher risktaking, innovation, proactivessnes and entrepreneurial intention. A research on all elements of EO found that entrepreneurial experience student scored higher than non-entrepreneurial experienced students (Taatila \& Down, 2012). Other researchers who have investigated students' IEO include Ekpe and Mat (2012) and Yajid, Khatibi, Azam, \& Ranasinghe (2019). As the topic is related to technopreneur, IEO is the best option as it is based on individual prospect.

Contextual element is one of the environment factor that contribute entrepreneurial intention as well this factor has big influence on entrepreneurial decision than personality factor (Gartner, 1989). Many studies such as Kristiansen and Indarti (2003; 2003), Lestari and Susetyo (2014), Mat, Maat and Mohd (2015) also has using contextual element as related construct towards entrepreneurial intention. According to Franke (2003), this factor can be identify as related concept of entrepreneurship supports and barriers. In this contextual element, it consists of three item which is access to capital, access to information and lastly is social networking. This item is the most visible influence on entrepreneur decision (Kirstiansen \& Indarti, 2003, 2004; Ramayah \& Harun, 2005).

The hypothesis of this study:

$\mathrm{H} 1$ : Contextual elements positively influence technopreneurial intention.

$\mathrm{H} 2$ : IEO mediates the relationship between contextual elements and technopreneurial intention.

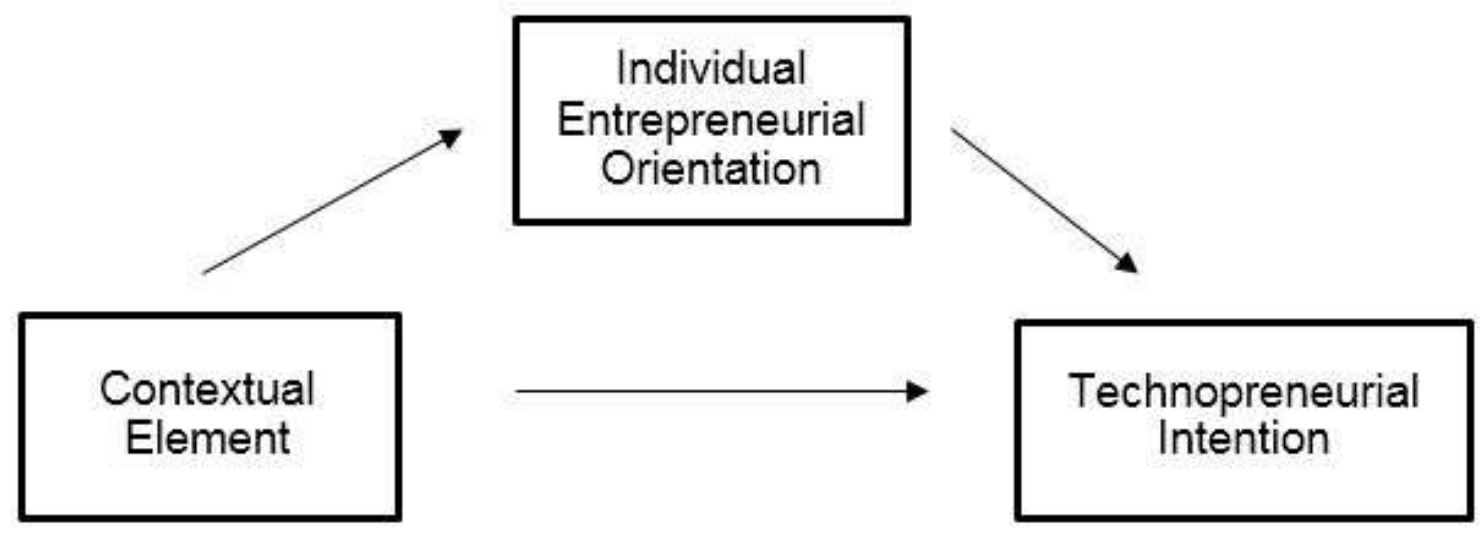

Figure 1: Theoretical framework of the study

\section{Methodology}

This study employed proportionate stratified random sampling in selecting respondent where a list name of sample derived from Academic Affair Unit (HEA) of local university in Malaysia. From total respondent, $36 \%$ respondent are male and $64 \%$ are female. All the construct of the study were measured with scales adopted from established measurements. For the technopreneurial intention, 
INTERNATIONAL JOURNAL OF ACADEMIC RESEARCH IN BUSINESS AND SOCIAL SCIENCES

Vol. 10, No. 6, June, 2020, E-ISSN: 2222-6990 @ 2020 HRMARS

this study has adopted the 6-items questionnaire constructed by Linan and Chen (2009). In example of the item adopted are "I am ready to do anything to be a technoprenuer" and "I am determined to create a technology based firm in the future". Meanwhile for contextual elements, 8-items questionnaire has been adopted where constructed by Kristiansen and Indarti (2003, 2004); Taormina and Lao (2006); Javier, Chamorro-mera and Rubio (2017). The example of items are "I have access to capital to start a business" and "It is easy to obtain a bank loan to start a business". Last not least, individual entrepreneurial orientation (IEO) consist of 10-items questionnaire constructed by Bolton and Lane (2012). The examples of IEO are "I like to take bold action by venturing into unknown" and "I prefer to my own unique way when learning new things rather than doing it like everyone else does". All the construct are using 7-likert scale (1-Strongly Disagree to 7-Strongly Agree). The data collected was analysed using Statistical Package for Social Sciences (SPSS) version 25.0. Simple regression test was been apply for hypothesis one $(\mathrm{H} 1)$ and Baron-Kenny method as used for hypothesis two $(\mathrm{H} 2)$.

\section{Result}

\section{Correlation}

Pearson correlation analysis was used in analysing data to ensure all variables were link each other. The result was presented in Table 1. Based on the table, the correlation coefficients for each path of variables is from 0.456 to 0.666 and statistically significant (sig. $<0.01$ ). As the values of the result is not too high, multicollinearity was not the problem. Thus, condition to test the mediator has been met and regression analysis can be performed.

Table 1: Correlation analysis all variable

\begin{tabular}{|l|c|l|l|}
\hline & $\begin{array}{l}\text { Individual } \\
\text { Entrepreneurial } \\
\text { Orientation }\end{array}$ & $\begin{array}{l}\text { Contextual } \\
\text { Element }\end{array}$ & $\begin{array}{l}\text { Technopreneurial } \\
\text { Intention }\end{array}$ \\
\hline $\begin{array}{l}\text { Individual } \\
\text { Entrepreneurial } \\
\text { Orientation }\end{array}$ & 1 & & \\
\hline $\begin{array}{l}\text { Contextual } \\
\text { Element }\end{array}$ & $0.523^{* *}$ & 1 & \\
\hline $\begin{array}{l}\text { Technopreneurial } \\
\text { Intention }\end{array}$ & $0.456^{* *}$ & $0.666^{* *}$ & 1 \\
\hline
\end{tabular}

\section{Regression}

Baron and Kenny method was adopted to test the two hypotheses $(\mathrm{H} 1$ and $\mathrm{H} 2)$ suggested. This method consist of four step condition to fulfil. For the first step, contextual element (independent variable) influence technopreneurial intention (dependent variable), showed as "path c"in Fig 2. Based on table 2 , the results show a positive and significant relationship $(\beta=0.666$; sig. $<0.001)$ between contextual element and technopreneurial intention. This showed that the first rules in Baron-Kenny test was achieved. Thus, hypothesis 1 (H1) was also supported. 
INTERNATIONAL JOURNAL OF ACADEMIC RESEARCH IN BUSINESS AND SOCIAL SCIENCES Vol. 10, No. 6, June, 2020, E-ISSN: 2222-6990 @ 2020 HRMARS

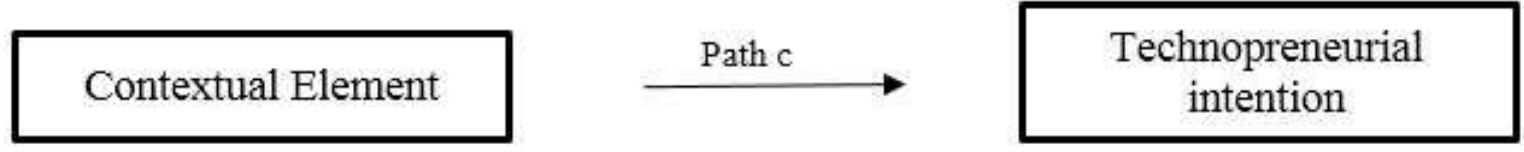

Figure 2: Path C

The second step, contextual element on individual entrepreneurial orientation, showed as "path $a$ " in Fig. 3. Table 3 were the results of the second step and it show that contextual element positively influence and significantly $(\beta=0.523$; sig. $<0.001)$ on individual entrepreneurial orientation. This showed that the second rules in Baron-Kenny test was fulfil.

Table 2: Regression analysis 1

\begin{tabular}{|l|c|c|c|}
\hline & $\begin{array}{l}\text { Standardized } \\
\text { Beta }\end{array}$ & $\mathrm{t}$ & Sig. \\
\hline $\begin{array}{l}\text { Contextual } \\
\text { Element }\end{array}$ & 0.666 & 10.856 & $<0.001$ \\
\hline F-statistics (sig.) & \multicolumn{3}{|c|}{$117.846(<0.001)$} \\
\hline $\mathrm{R}^{2}$ & \multicolumn{3}{|c|}{0.443} \\
\hline
\end{tabular}

Dependent variable: Technopreneurial Intention

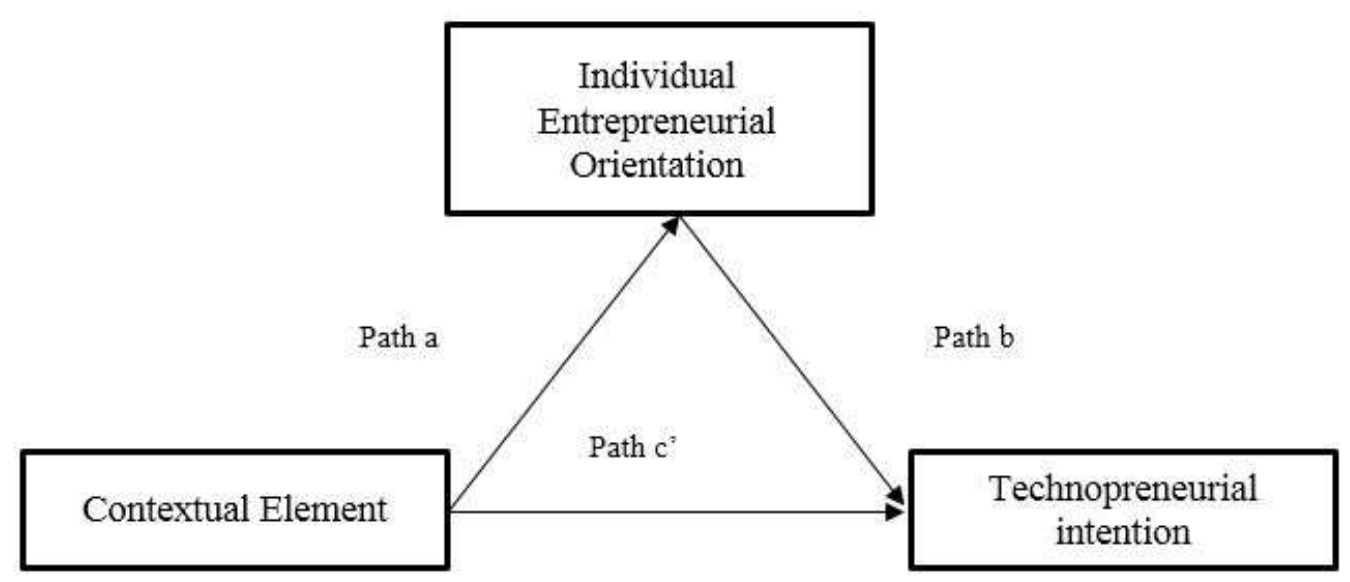

Figure 3: Path a, Path b, Path c'

The third step was to determine to what extant did contextual element and individual entrepreneurial orientation influence the technopreneurship intention. The relationship was 
INTERNATIONAL JOURNAL OF ACADEMIC RESEARCH IN BUSINESS AND SOCIAL SCIENCES Vol. 10, No. 6, June, 2020, E-ISSN: 2222-6990 @ 2020 HRMARS

explained as "path b" and "path c" in Fig. 3. Table 4 show the regression results where the individual entrepreneurial orientation and technopreneurial intention is positively and significant $(\beta=0.149$; sig. $0.039)$ which is below $5 \%$ significant level.

The forth step where the last step was to compare the standardized beta of path c and path $\mathrm{c}^{\prime}$. The values of standardized beta both were derived from Table 2 and Table 4 . The standardized beta decrease from 0.666 to 0.588 . In addition, $R^{2}$ also increased from 0.443 to 0.459 . Although the standardized beta value decrease is small, it can be conclude that, there was a partial mediating effect of individual perception between contextual element and technopreneurial intention.

Table 4: Regression analysis 3

\begin{tabular}{|l|c|c|c|}
\hline & $\begin{array}{l}\text { Standardized } \\
\text { Beta }\end{array}$ & $\mathrm{t}$ & Sig. \\
\hline $\begin{array}{l}\text { Contextual } \\
\text { Element }\end{array}$ & 0.588 & 8.264 & $<0.001$ \\
\hline $\begin{array}{l}\text { Individual } \\
\text { Entrepreneurial } \\
\text { Orientation }\end{array}$ & 0.149 & 2.088 & 0.039 \\
\hline F-statistics (sig.) & $62.440(<0.001)$ & \\
\hline $\mathrm{R}^{2}$ & \multicolumn{3}{|c|}{0.459} \\
\hline
\end{tabular}

Dependent variable: Technopreneurial Intention 
INTERNATIONAL JOURNAL OF ACADEMIC RESEARCH IN BUSINESS AND SOCIAL SCIENCES Vol. 10, No. 6, June, 2020, E-ISSN: 2222-6990 @ 2020 HRMARS
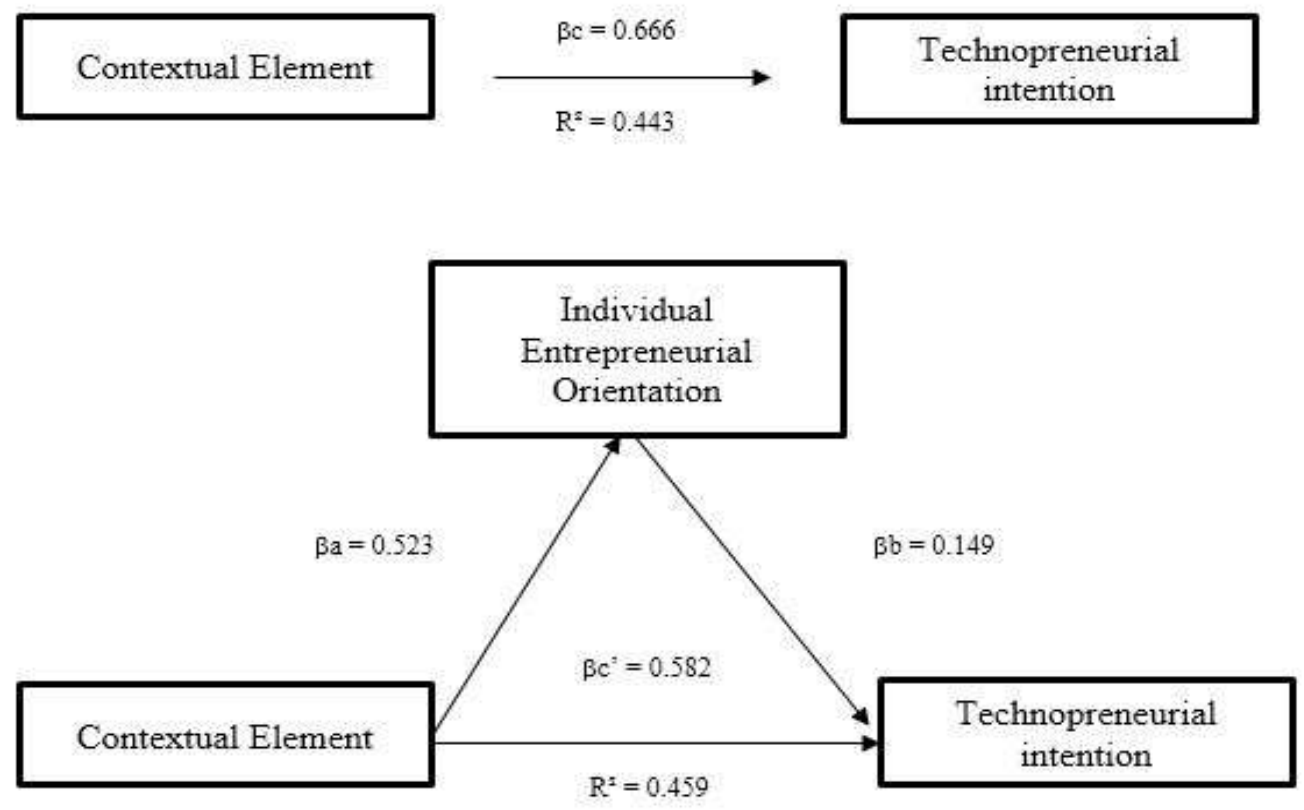

Figure 4: Comparisons of Path $\mathrm{c}$ and Path $\mathrm{c}^{\prime}$

Table 5: Comparison of Standardized beta of Path c and Path c'.

\begin{tabular}{|l|c|c|l|}
\hline & $\begin{array}{l}\text { Standardized Beta } \\
\text { Path c }\end{array}$ & $\begin{array}{l}\text { Standardized Beta } \\
\text { Path c' }\end{array}$ & Results \\
\hline Contextual Element & 0.666 & 0.588 & Partially mediation \\
\hline
\end{tabular}

Mediator: Individual Entrepreneurial Orientation

Dependent variable: Technopreneurial Intention

Regression results indicated that a partially mediating effect of individual entrepreneurial orientation between contextual element and technopreneurial intention. Sobel's test was implemented to determine the indirect effect and whether such mediating effect was significance. The results were shown in Table 6. The z-score (2.00) and sig. value (0.04) confirmed that indirect effect of individual entrepreneurial orientation between contextual element and technopreneurial intention was significant. Based on Baron-Kenny test, the mediation is partially and Sobel 's test result is significant, thus hypothesis $2(\mathrm{H} 2)$ was partially supported.

Table 6: Results of Sobel's Test

\begin{tabular}{|l|c|c|c|c|c|c|}
\hline Relationship & $\mathrm{a}$ & $\mathrm{Sa}$ & $\mathrm{b}$ & $\mathrm{Sb}$ & $\mathrm{z}$ & Sig. \\
\hline CE - IEO - TI & 0.366 & 0.049 & 0.281 & 0.135 & 2.00 & 0.04 \\
\hline
\end{tabular}

\section{Discussion}

Based on the analyses performed, the first hypothesis ( $\mathrm{H} 1)$ was supported. The contextual element significantly influence technopreneurial intention. The result consistent with previous study conducted by Mat, Maat and Mohd, (2015); Kristiansen and Indarti, (2004) and Setiobudi and Herdinata, (2018). Meanwhile, the second hypothesis (H2) was partially supported. Individual entrepreneurial orientation (IEO) partilly mediated the relationship between contextual element and 
technopreneurial intention. The findings found in this study support the previous study that individual entrepreneurial orientation is main factor of entrepreneurial intention (Luthje \& Frank, 2003; Duijn, 2009; Awang et al., 2016). The mediation in this study is partial, which mean that, there is other factor can mediate the relationship but IEO still can be reliable factor that influence the relationship. The outcome explained that contextual element influenced individual entrepreneurial orientation and individual entrepreneurial orientation also consequently affected technopreneurial intention. Thus, from the relationship, individual entrepreneurial orientation could not be forgotten as one of the main factor of technopreneurial intention.

\section{Conclusion}

This study conducted to determine whether there is relationship between contextual element, technopreneurial intention and individual entrepreneurial orientation as mediator. Based on the study result, it could be concluded that contextual elements significantly influenced the technopreneurial intention. In addition, the relationship between contextual elements and technopreneurial intention was significantly partial mediated by individual entrepreneurial orientation. Since the contextual elements positively related with technopreneurial intention, it is suggested that university should explore more by providing graduate grant scheme for student and maybe university could collaborate with big company for student who interested in this segment where it could boost student spirit and fulfill their desires. Furthermore, government could give grant or give instant capital and advise for graduate to startup their business nature freely but still under supervision and monitor by government agency. Based on the suggestion, it is hoped that it could help overcome the problems such as limited number of entrepreneurs as well technopreneurs and giving a clear picture about technopreneur in Malaysia.

\section{Acknowledgement}

The authors gratefully acknowledge the help of the Ministry of Higher Education Malaysia (MOHE) for gratefully funding this research project under the Fundamental Research Grant Scheme (FGRS) [600-IRMI/FRGS 5/3 (043/2019)] [FRGS/1/2018/SS03/UITM/02/12] and Universiti Teknologi MARA (UiTM), Malaysia for support and motivation.

\section{References}

Awang, A., Amran, S., Nor, M. N. M., Ibrahim, I. I., \& Razali, M. F. M. (2016). Individual Entrepreneurial Orientation Impact on Entrepreneurial Intention: Intervening Effect Of PBC and Subjective Norm. Journal of Entrepreneurship, Business and Economics, 4(2), 94-129.

Bank, W. (2018). Malaysia's Digital Economy: A New Driver of Developmnent. World Bank Group. https://doi.org/10.1596/30383

Bolton, D. L., \& Lane, M. D. (2012). Individual entrepreneurial orientation: Development of a measurement instrument. Education and Training, 54(2-3), 219-233. https://doi.org/10.1108/00400911211210314

Duijn, W. (2009). Entrepreneurial intention among FDEWB students. Retrieved from http;//studiosus.nl.

Ekpe, I., \& Mat, N. (2012). The Moderating Effect of Social Environment on the Relationship between Entrepreneurial Orientation and Entrepreneurial Intentions of Female Students at Nigerian Universities. International Journal of Management Sciences and Business Research, 1(4), 1-16. 
INTERNATIONAL JOURNAL OF ACADEMIC RESEARCH IN BUSINESS AND SOCIAL SCIENCES

Vol. 10, No. 6, June, 2020, E-ISSN: 2222-6990 @ 2020 HRMARS

EY. (2019). Redesigning for the digital economy: A study on SMEs in Southeast Asia.

Franke, N., \& Luthje, C. (2003). The 'making ' of an entrepreneur : testing a model of entrepreneurial intent among engineering students at MIT, 135-147.

Javier, F., Chamorro-mera, A., \& Rubio, S. (2017). Academic entrepreneurship in Spanish universities : An analysis of the determinants of entrepreneurial intention. European Research on Management and Business Economics, 23(2), 113-122.

https://doi.org/10.1016/j.iedeen.2017.01.001

Kristiansen, S., \& Indarti, N. (2003). Determinants ofEntrepreneurial Intention: The Case of Norwegian Students. Gadjah Mada International Journal of Business, 5(1), 79-95.

Kristiansen, S., \& Indarti, N. (2004). Entrepreneurial intention among Indonesian and Norwegian students. Journal of Enterprising Culture (JEC), 12(01), 55-78. Retrieved fromhttps://econpapers.repec.org/RePEc:wsi:jecxxx:v:12:y:2004:i:01:n:s021849580400004x

Krueger, \& Brazeal. (1994). Entrepreneurial Potential and Potential Entrepreneurs. Entrepreneurship Theory and Practice, 91-104.

Liñán, F., \& Chen, Y. (2009). Development and Cross-Cultural Application of a Specific Instrument to Measure Entrepreneurial Intentions, 593-617.

Lumpkin \& Dess. (1996). Clarifying the entrepreneurial orientation construct and linking it to performance. Academy of Management Review, 21(1), 135-172.

Mat, S. C., Maat, S. M., \& Mohd, N. (2015). Identifying Factors that Affecting the Entrepreneurial Intention among Engineering Technology Students. Procedia - Social and Behavioral Sciences, 211(September), 1016-1022. https://doi.org/10.1016/j.sbspro.2015.11.135

Robinson, \& Stubberud, H. A. (2014). Elements Of Entrepreneurial Orientation and Their Relationship to Entrepreneurial Intent. Journal of Entrepreneurship Education, 17(2), 1-12.

Setiobudi, A., \& Herdinata, C. (2018). Difference in entrepreneurial intention on generation $X, Y$ and Z. International Journal of Academic Research in Business and Social Sciences, 8(7), 49-58. https://doi.org/10.6007/IJARBSS/v8-i7/4323

Taatila, V., \& Down, S. (2012). Measuring entrepreneurial orientation of university students. Education and Training, 54(8), 744-760. https://doi.org/10.1108/00400911211274864

Taormina \& Lao. (2006). Measuring chinese entrepreneurial motivation personality and environmental influences. International Journal of Entrepreneurial Behavior \& Research, 13(4), 200-221. https://doi.org/10.1108/13552550710759997

Yajid, M. S. A., Khatibi, A., Azam, S. M. F., \& Ranasinghe, H. K. G. S. (2019). Individual entrepreneurial orientation and graduate business performance of the University of Sri Jayewardenepura in Sri Lanka. Pressacademia, 6(1), 44-61. https://doi.org/10.17261/pressacademia.2019.1033 